merits. ${ }^{113}$ Such controversies could be discouraged by requiring the trial judge to fix the proper attorney's fee in the judgment in cases where it is proper to award costs, leaving to the clerk or taxing officer the taxation of only actual disbursements and unimportant items, after entry of judgment. ${ }^{14}$

The precise details in the administration of the reform suggested here are beyond the scope of a preliminary study, designed broadly to point out the anomalous condition of the present law of costs, the resulting abuses and a possible remedy for them. Inevitably, the operation of the procedure can only be sketched in outline and general meaning; practical application in a variety of situations would necessarily await the work of the courts. Yet it may be stated with confidence that the proposed reform would be a significant step in the long struggle for better administration of justice.

\title{
THE CONSTITUTIONALITY OF PRIVATE ACTS OF CONGRESS
}

StatuTes which apply to only one or a few named individuals ${ }^{1}$ each year in the United States outnumber public bills by a large majority. ${ }^{2}$ In the state legislatures this annual barrage of special legislation is laid down in spite of explicit constitutional restrictions designed to limit the type and number of special statutes, and in the face of a mass of restrictive case law developed by the courts. ${ }^{3}$ Congressional exercise of private-bill functions, on the other hand, is free from specific constitutional restraint - except for a prohibition against bills of attainder ${ }^{4}$ - and has, to date, apparently been questioned by the judiciary only four times. ${ }^{5}$

113. This fear was expressed with reference to the award of counsel fees as an element of damages in Oelrichs v. Spain, 15 Wall. 211, 230 (U. S. 1872).

114. That is the civil law practice. See P. R. Code Crv. Proc. $\$ 339$.

1. The statutory definition of Congressional private bills includes "bills for the relief of private parties, bills granting pensions, bills removing political disabilities, and bills for the survey of rivers and harbors." 33 STAт. 611 (1905), 44 U. S. C. $\$ 189$ (1934). A functional classification, however, excludes rivers and harbors bills and includes . bills which, though catalogued as public, affect directly only one or a few determinable individuals. For most purposes of this study, the functional definition is controlling. Sce Luce, Legislative Problems (1935) 532-536.

2. The Seventy-Fifth Congress enacted 834 private and 1410 public bills. But the proportion in the state legislatures is inverse. See Luce, op. cit. supra note 1, at 545.

3. See Cloe and Marcus, Special and Local Legislation (1936) 24 KY. L. J. 351.

4. U. S. Const. Art. I, $\$ 9$.

5. Jones v. Meehan, 175 U. S. 1 (1899); Pennsylvania v. Wheeling \& Belmont Bridge Co. et al., 18 How. 421 (U. S. 1855); Paramino Lumber Co. et al. v. Marshall, 27 F. Supp. 823 (D. Wash. 1939), cert. granted, U. S. Sup. Ct. Docket No. 271 (1940); Pocono Pines Assembly Hotels Co. v. United States, 73 Ct. Cl. 447 (1932). 
This comparative freedom of Congress in the realm of private legislation is explicable only through a consideration of the narrow range within which constitutional conflict over the federal private-bill power can arise. From the beginning, the subject matter of special Congressional legislation has been limited by the division of governmental activities between state and federal legislatures. $^{6}$ In the states, the regulation of corporations, insurance, public utilities and domestic relations has presented manifold opportunity for the award of special privilege. ${ }^{\top}$ On the other hand, the sphere of Congressional legislative activity, so far as private bills are concerned, was confined originally to the grant of pensions and the allowance of claims, with regulation of the civil service and of re-issue patents to be added soon after $18000^{8}$

A second limiting factor has been the tendency continually to delegate the consideration and approval of troublesome classes of private petitions to the courts or to federal agencies created to administer the relief required." Two impulses have determined this evolution. The volume of private petition for Congressional favor creates a burden upon legislative time which is impossible to sustain without generally dispensing with an inquiry into the merits of the cases presented. Moreover, the opportunities for log-rolling between Congressmen, each with a pocket-full of bills from plaintive constituents, have stimulated demands for a procedure to eliminate at least a portion of the potential abuse. ${ }^{10}$ The result has been a series of delegations, beginning with an unsuccessful attempt to transfer all pension claims to the courts, which has created a body of federal agencies to assist in the administration of the sovereign favor. The first institutional outgrowth of the specialization process was authorization for a Pension Bureau in the War Department.11 But even after the enactment of sweeping military insurance and compensation laws beginning with $1917,{ }^{12}$ pleas for exception to the pension rules have shifted back to Congress a sizable proportion of the burden so delegated.13 The

6. Compare Art. I, $\$ 8$ of the Federal Constitution with the Tenth Amendment.

7. Luce, op. cit. supra note 1, at 540-49; Chasmerlais:, Legrstative Processes, Nattonal and State (1936) 237-242.

8. See, generally, U. S. STATUTES AT L.ARge (1862) Vol. 6 , which compiles private acts passed, 1789-1845. Aside from the four large groups of private acts named, there have been hundreds of miscellaneous types of acts which fit into no particular category and which seldom recur.

9. Those classes of private petitions which Congress has not delegated to an independent agency for consideration are parceled out among the regular committees according to subject matter. RULES of tHe House of Representratives (1927) \$§ 827-832; Senate MIAxual (1936) $\$ \$ 22-44$. Compare with this the highly specialized procedure of the English Parliament, which in many ways resembles that of a court. Dosd A:n Winberforce, Private Bitl Procedure (1898).

10. See Luce, Petty Business in Congress (1932) 26 Azr. Por. Scr. Rev. S15; Luce, op. cit. supra note 1, at 540-49; MLAyo, Soldiers, WHAt Next? (1934).

11. Glasson, Federal Militaky Pensions in the Uitited States (1918) 54-97.

Weber, The Bureau of Pensions (1923).

12. 40 Stat. 398 (1917).

13. See generally U. S. Statutes at L.iRge (1937) Vol. 50. 
situation was particularly bad after the Civil War, when President Cleveland set a veto record between 1885 and 1889 in the destruction of 228 private pension bills. ${ }^{14}$ A second delegation made by Congress to escape the pressure of private petition was the transfer of the re-issue of patents to a commissioner in 1836; until then, application for extensions of the original patent privilege had been made directly to Congress. ${ }^{15}$

The doctrine of the sovereign's immunity to suit, inherited from the common law, had become so prolific a source of maladministration that Congress in 1855 created a Court of Claims, ${ }^{10}$ empowered in $1863^{17}$ and $1887^{18}$ to determine and adjudicate certain restricted classes of contract claims, as well as to investigate others in an advisory capacity. ${ }^{10}$ A series of acts after 1910 authorized settlement of tort claims in limited character and amount by the federal departments concerned. A Small Claims Act in 1922 extended the settlement power of all departments to $\$ 1,000$ in cases of property damage. ${ }^{20}$ To date, however, efforts to establish a court to hear all claims in tort against the Federal Government by permanent waiver of immunity for that purpose have failed. ${ }^{21}$

The possibility of constitutional conflict over the private-act power of Congress, already considerably restricted by limitations on the scope of the power which result from the division of state and federal activities, and from delegation to special agencies, hạs been further reduced by the character of the majority of current private enactments. Approximately ninety percent of these enactments authorize payments by the Government. ${ }^{22}$ The remainder grant costless emoluments, bestow honors, memorialize the dead. The taxpayer is legally incapable of challenging such incursions on the Treasury ${ }^{2 B}$ - aside from a resort to the ballot - and no legal interest cognizable in the courts is created by the award of a decoration, no matter how ill-deserved.24 Private bills of this character are therefore unchallengable in the absence of a specific provision in the Constitution forbidding the grant of privilege.

The omission of any such provision has thus vastly reduced the probability of any judicial review of the federal private-bill power. This, however, has

14. See GLasson, op. cit. supra note 11, at 273-80.

15. See generally Brown, A Brief History of Patent Legislation in the United States (1889).

16. 10 Stat. 612 (1855).

17. 12 Stat. 765 (1863).

18. 24 Stat. 505 (1887).

19. The best summary of the development of the Court of Claims appears in an opinion by Booth, Chief Justice, in Pocono Pines Assembly Hotels Co. v. United States, 73 Ct. Cl. 447 (1932).

20. 42 StAT. 1066 (1922) 31 U. S. C. $\$ 215$ (1934).

21. Borchard, The Federal Tort Claims Bill (1933) 1 U. of CEI. L. REv. 1. The largest single class of claims presented to Congress today springs from damage wrought by government automobiles.

22. See generally U. S. Statutes at Large (1937) Vol. 50.

23. Massachusetts v. Mellon, 262 U. S. 447 (1923).

24. At least no case of such a challenge is recorded. 
not been true in the states. There widespread abuses of the power to legislate for individual cases aroused a storm of hostility to private and other special types of legislation which swept through America after 1850, leaving constitutional restrictions in the states upon many kinds of private acts. ${ }^{25}$ Change knocked even at the door of Congress in the shape of amendments presented thirteen times between 1876 and 1909, by which it was hoped to restrain the private-bill power. ${ }^{26}$ The collapse of these efforts has left the Federal Constitution free from provisions like those which have so substantially curtailed the private-bill activities of the state legislatures.

Perhaps the most important factor of all in limiting litigation orer privatebill powers has been the restraint with which Congress has employed its prerogative. This has been especially important in respect to the enactment of bills which attempt to alter the legal relations existing between individuals. Two rough categories of private acts are distinguishable: those which deal with clearly legislative concerns - the grant of a pension, the promotion of an employee; and those which fall within the quasi-judicial sphere $-a$ decree of divorce, the alteration of a judgment. Since, for reasons presented, ${ }^{27}$ the former group is unchallengable in the courts, it is in the second area that Congressional restraint has been most significant.

To date there appear to have been but four instances where the courts have reviewed Congressional private legislation of a quasi-judicial character. ${ }^{\text {s }}$ Two of the four cases involved attempts by Congress to set aside judgments rendered by the federal judiciary. In view of the jealous care with which the courts since $M c C_{u}$ llough $v$. Virginia ${ }^{20}$ have protected their decisions from legislative alteration, it is paradoxical to discover that on both these occasions they sustained the private statute.

The first of these cases arose when the United States Supreme Court, at the suit of Pennsylvania, in May, 1852, ordered proprietors of bridges across the Ohio River near Wheeling to make changes in the structures sufficient to remove obstructions to navigation..$^{30}$ In August of that same year Congress by statute announced: "That the bridges . . . are hereby declared to be lawful structures in their present positions and elevations, and shall be so held and taken to be, anything in the law or laws of the United States to the contrary notwithstanding." 31 Although this Congressional Act destroyed the rights of Pennsylvania obtained in the first decree, the Court, in Pcnu-

25. See Cloe and Marcus, stipra note 3.

26. Listed in Musaranno, Proposed Aarendasents to the Constriution (1929) 149-50.

27. See p. 714 supra.

28. Cited stpra note 5 .

29. 172 U. S. 102 (1898).

30. Pennsylvania v. Wheeling \& Belmont Bridge Co. ct al., 13 How. 518 (U. S. 1851).

31. 10 Stat. 112 (1852). In form this bill was a rider to an appropriation for the Post Office Department. 
sylvania v. The Wheeling \& Belmont Bridge Company, ${ }^{32}$ preserved intact its theory of judicial supremacy by sacrificing the interests of Pennsylvania. Declaring the statute constitutional, Mr. Justice Nelson explained that the original decree was executory only, dependent upon a continuing violation of the public right for its effect. Since Congress had seen fit to waive the public right, the nuisance no longer obtained. However, ". . . if the remedy in this case had been an action at law, and a judgment rendered in favor of plaintiff for damages, the right to these would have passed beyond the reach of Congress." 33

The prophetic words of Mr. Justice Nelson remained untested until the Pocono Pines case in $1932 .{ }^{34}$ There Congress, in terms, had deprived a stccessful plaintiff of his judgment in the Court of Claims by ordering that court, in a private statute, ${ }^{35}$ to hear relitigation of the cause. Since the original judgment had been rendered by the court in its judicial, not its advisory, capacity, the statute was a challenge to the finality of a judicial decrec. Nevertheless, following the technique exemplified in the Whoeling case, the court avoided a declaration of unconstitutionality by a construction of the statute which went against the plaintiff. "A pronounced and vitally different situation" would obtain, the court asserted, had plaintiff procured a valid judgment against the United States and had Congress "sought to stbject its permanency to the hazard of a new trial. A judgment, if lawful, is property and so recognized by law."36 An indignant dissent pointed out that Congress had done precisely that, but again the private-bill power had invaded the judicial province and come away unscathed.

The one rebuke suffered by Congress came in 1899 in the Supreme Court case of Jones v. Meehan, ${ }^{37}$ some thirty years before the Pocono Pines decision. There Congress had attempted to invalidate a land title by means of a private statute. $^{38}$ In an opinion so terse as to suggest the lack of any doubt upon the fundamental principle involved, Mr. Justice Gray stated that the property rights in question "could not be divested by any subsequent action of the lessor, or by Congress, or of the executive departments." 30

An analysis of these three cases is hardly one upon which to erect catcgorical conclusions. ${ }^{40}$ It is reasonably apparent that the courts may, when

32. 18 How. 421 (U.S. 1855). See Congressional debates in (1852) 25 Cong. Gtone: 965-1068. 1855).

33. Pennsylvania v. Wheeling \& Belmont Bridge Co. et al., 18 How. 421,424 (U. S.

34. Pocono Pines Assembly Hotels Co. v. United States, 73 Ct. Cl. 447 (1932).

35. 46 Stat. 1622 (1931).

36. Pocono Pines Assembly Hotels Co. v. United States, $73 \mathrm{Ct}$. Cl. 447, 495-496 (1932).

37. 175 U. S. 1 (1899).

38. 28 STAT. 1018 (1894).

39. Jones v. Meehan, 175 U. S. 1, 32 (1899).

40. The only specific reference to private statutes in the literature of the Supreme Court is a Marshall dictum of 1827 that "There are, undoubtedly, great and solid objections to legislation for particular cases. But these objections do not necessarily make 
faced with a bald assertion of Congressional power in the judicial sphere, avoid the shock of open conflict by construing away the offensive features of a given private bill. It is also reasonably clear that the more certain the courts become that the threatened private interest is a "property" right, the more probable a declaration of unconstitutionality.

Recently, the competition of court with legislature has entered new fields. A contest for the control of administrative tribunals has been fought, by the legislature with liberal delegations of power to hear and decide; by the courts with a consistent effort to impose on the proceedings of administrative commissions the requirements of judicial due process. ${ }^{11}$

Against this background, in Paramino Lumber Company ct al. v. Marshall.42 a fourth quasi-judicial exercise of the private-bill power by Congress is recognizable as an attempt to bend the still untested private-statute technique to new tasks in the field of administrative regulation. On April 10, 1936, Congress passed a private act ${ }^{43}$ for the relief of John T. Clark of Seattle, initiating a controversy which has now proceeded to the Supreme Court. Clark, a maritime worker, had been injured in 1931 while at work on board ship in Seattle harbor, and had received compensation from his employer's insurer under provisions of the Federal Employees' Compensation Aet.44 By an order of August 26,1931, the deputy commissioner at Seattle, charged with enforcement of the federal act, had ordered Clark's case closed as of July 4, 1931, when Clark's physician pronounced him recovered. Thirty days after that date, in accordance with the compensation statute, the award beeame final. Subsequent to the termination of the case, Clark's injury reappeared under circumstances of particular hardship. After considerable investigation, ${ }^{45}$ Congress was moved to pass the private act in question, which empowered the deputy commissioner to reopen Clark's case. ${ }^{20}$ An additional $\$ 4,000$ award followed. An application to enjoin the enforcement of the commissioner's second order was denied by a three-judge federal district court in Seattle.

such legislation repugnant to the Constitution of the United States." Williams v: Xorris, 12 Wheat. 117, 128 (U. S. 1827). Reference was to an act of the legislature of Tennessee, not to one of Congress.

41. Note, for example, the tendency of courts to require common law procedural safeguards in administrative proceedings, discussed in Comment (1931) 80 U. of PA. L. Rev. 96; Olson, Due Process-Notice, Hearing and Recica (1935) \& So. Calm. L. Rev. 330; Hanft, Utilities Commissions as Expert Courts (1936) 15 N. C. L. REv, 12.

42. 27 F. Supp. 823 (D. Wash. 1939), cert. granted, U. S. Sup. Ct. Doeliet No. 271 (1940).

43. 49 StAT. 2244 (1936).

44. 44 STAT. 1436 (1927), 33 U. S. C. $\$ 901$ (1934). In 1934 the act was amended to extend the time for re-examination in all cases to one year. $48 \mathrm{STAr} .80 \mathrm{f}, 33 \mathrm{U}$. S. C. $\$ 922(1934)$.

45. Sen. Rep. No. 1645, 74th Cong., 2d Sess. (1936).

46. The Clark Bill as originally introduced followed the usual pattern of private-bill legislation; it authorized payment of an award to Clark from the Treasury. In this form it would have been impervious to constitutional attack. See 80 Cosc. Rec. 1475-6 (1936). 
Since the only limitation upon the private-bill power of Congress suggested by the courts to date has been the protection due property rights, either under the doctrine of separate powers, as in the Wheeling case or as in Jones v. Meehan, by an invocation of the substantive guaranties implicit in due process, constitutional attack upon the Clark Bill must be phrased in terms of the Fifth Amendment. 47

Even the most favorable interpretation of the Bill must recognize that, in withdrawing from employer and insurer their immunity from further proceedings, it subjects them to responsibilities not borne by other employers and insurers similarly situated. There is little doubt that such an enactment by a state legislature could be found in conflict with the equal protection clause of the Fourteenth Amendment. ${ }^{48}$ This remains largely hypothesis, however, for no application of the equal protection clause by the Supreme Court has yet been made to state private legislation, probably because state restrictions on special acts have been adequate. The absence of an equal protection clause in the Fifth Amendment has prevented the application of that doctrine to federal private statutes; but since the expansion of due process of law to the proportions of a substantive guaranty, the courts have talked loosely of equality of protection as one test of the reasonable treatment which due process has been made to require. ${ }^{40}$ In 1930 , this test of due process was clearly incorporated in the substantive law of the Fifth Amendment by the Supreme Court's decision in Chicago, Rock Island \& Pacific Railway v. United States. ${ }^{50}$ Even under this case, however, the equal protection requirement as applied to federal acts is considerably less stringent than that imposed upon state private acts by the Fourteenth Amendment. The validity of a state private-bill may be questioned on the sole ground of equal treatment; ${ }^{51}$ invalidation of a federal statute involves a broader inquiry in terms of due process, of which equality of treatment is but a part. Thus, unless the interest threatened is "property" and the power exercised is clearly unreasonable, a lack of equality of treatment may not justify a declaration of unconstitutionality. ${ }^{52}$ For that result it is necessary, even under a rigorous application of the Rock Island case, that the court supplement its finding of a violation of equal protection by a further decision that the immunity

47. "No person shall be . . . deprived of life, liberty, or property, without due process of law . . ." U. S. Const., AMENd. V.

48. "No State shall . . . deny to any person within its jurisdiction the equal protection of the laws." U. S. Const., AMEnd. XIV.

49. See Hurtado v. California, 110 U. S. 516, 535 (1884); Leeper v. Texas, 139 U. S. 462, 468 (1891); Caldwell v. Texas, 137 U. S. 692, 697 (1891); Giozza v. Tiernan, 148 U. S. 657 (1893); United States v. Yount, 267 Fed. 861, 863 (D. Penn. 1920); United States v. Ballard, 12 F. Supp. 321, 326-7 (D. Ky. 1935); Wallace v. Currin, 95 F. (2d) 856,867 (C. C. A. 4th, 1938).

50. 284 U. S. 80 (1931).

51. See Truax v. Corrigan, 257 U. S. 312, 331 (1921).

52. See cases cited sttpra note 49. 
created by an administrative award is "property" and that this "property" has been taken without "due process of law."

The real issue in the Paramino case, and the pivotal question in determining whether any similar private bill of Congress is constitutional or not, is how far Congress will be permitted to go in re-arranging the award of the compensation commission, and to what extent that award is to be protected from Congressional meddling by the courts. The issue is discussed in the courts, however, only in the language of theory. The question is posed as a decision as to whether the employer's freedom from further proceedings before the commissioner can be called a "property" interest and therefore protected from change by Congress; or whether it is to be classed as a legal interest of lesser status, in which case Congress can be given a free hand with it. In this discussion the legal interest which was given to Clark's emplojer and insurer by the expiration of the 30-day limit on re-opening the case is called an immunity, and the question becomes then whether this particular kind of an immunity is "property." In view of the divided authority on the classification of immunities gained by the operation of this sort of limitation, it may be illuminating to examine the treatment accorded analogous immunities by the courts.

The most important class of similar immunities which have been studied by the courts are those created when a statute of limitations cuts off a civil right of action..$^{53}$ No distinction need be made between public and private acts in these cases, for in either event the concern of the courts is the extent to which the legislature is to be allowed to go, and whether public or private the act will be unconstitutional if the immunity is called property. In actions involving real property, potential defendants receive an immunity from litigation after the expiration of the statute of limitations of which the legislature may not deprive them by retroactive extension of the statute. But an immunity from the litigation of a contract claim is not so protected by the federal courts, ${ }^{55}$ although there are many state authorities to the contrary. ${ }^{56}$ Dictum by Mr. Justice Butler in Danzer v. Gulf \& Ship Island Railroad ${ }^{57}$ suggèsts a classification of immunities along such lines as these: an immunity from litigation of a claim founded on common-law rights is not protected from destruction by the legislature as property under the Fifth Amendment; an immunity from litigation of a claim of statutory origin is property. The theoretical explanation of this distinction is that common law rights exist even after the statute of limitations expires, with merely their enforcement barred; whereas statutory rights cease to be at the end of the

53. See cases cited infra notes 54-58.

54. Stewart v. Keyes, 295 U. S. 403 (1935).

55. Campbell v. Holt, 115 U. S. 620 (1885) ; cf. Home Ins. Co. ct al. v. Dicls cl al., 281 U. S. 397 (1930), which, if applied, apparently would overrule Campbell v. Holt.

56. Collected in (1925) 36 A. L. R. 1316.

57. 268 U. S. 633 (1924). 
period designating their span of effectiveness. It follows that the revival of a statutory claim involves, as that of a common-law claim does not, the creation of new rights and duties - a result which, if achieved retrospectively, deprives the party proceeded against of his immunity, which, the doctrine further assumes, "vested" in him at the expiration of the legal relations created by the statute. ${ }^{58}$ This classification fails to take into account the unanimous application of the property tag, by the federal courts, ${ }^{50}$ to immunities arising from limitations on the litigation of claims to real property - common law rights.

The contradictory judicial treatment accorded immunities created by the operation of a statute of limitations on civil rights of action is reflected in cases which involve, like the Paramino case, an immunity created by a statute limiting the time during which the review of a compensation award may be applied for. The courts speak of "vested" rights when they wish to uphold the immunity against any attempt of the legislature to extend the limitation retrospectively. If the courts wish to give effect to the legislative purpose, the extension of the limitation on review is called a "procedural" change. "The rights of parties cannot be changed by legislation, but no party has a vested right in any particular remedy." " 0 At least eight cases in state courts, both within and without the private bill field, where the issue of the Paramino case is involved, have used the vested right doctrine to invalidate the legislative extension of statutes which limited the time for review of an original compensation award. ${ }^{61}$

Massachusetts has flatly defined the immunity imparted by expiration of the time for readjustment as a vested right, ${ }^{62}$ apparently overlooking early liberal constructions of statutes of limitation in the opinions of Mr. Justice Holmes. ${ }^{63}$ Inlinois aligned itself with Massachusetts in 1924.64 A large number of decisions give effect to the policy against legislative alteration of the limiting period by construing away the offensive features in statutes which attempt to suspend the limitation; but almost unanimously the opinion is expressed that, were circumvention impossible, the court would employ the

58. This is outlined in The Harrisburg, 119 U. S. 199 (1886). A contrary view as to compensation statutes, with a summary of authorities in the compensation ficld which follow this reasoning, is contained in Pine v. Industrial Comm., 148 Okla. 200, 298 Pac. 276 (1931).

59. See note 54 supra.

60. Willard v. Harvey, 24 N. H. 344,352 (1852).

61. Cited infra notes 62-66.

62. Casieri's Case, 286 Mass. 50, 190 N. E. 118 (1934) ; Ziccardi's Case, 287 Mass. 588, 192 N. E. 29 (1934).

63. Danforth v. Groton Water Co., 178 Mass. 472,59 N. E. 1033 (1901) ; Dunbar v. Boston \& P. R. R., 181 Mass. 383, 63 N. E. 916 (1902).

64. Arnold \& Murdock v. Industrial Comm. et al., 314 Ill. 251, 145 N. E. 342 (1924). But $c f$. Illinois cases cited infra note 70. 
"property" technique. ${ }^{\text {"J }}$ Attempts by the legislatures of Oregon and Montana to intervene in compensation cases in order to permit a re-examination of the award have fallen before constitutional restrictions on special legislation. ${ }^{66}$

If the immunity created by the 30-day limitation in the Paramino case were to be described by the Supreme Court in the language of these state cases, there would be little doubt that Congress, in enacting the private statute which deprived employer and insurer of that immunity, had talien from them "property." But cases reaching a contrary result upon precisely the same issue are equally numerous. In Independint Pior Company $:$. Yorlon, a case involving the identical federal statute of the Paramino case, the employee received compensation under the act by virtue of an order which became final April 2, 1934. On May 20, 1934. Congress amentul the Act, providing for reopening of any case within a year after the last pazment. The limitation in effect had closed the case on Nay 2.69 The procectings were re-opened, but the employer, Judge Dichinson ruled, was not deprived of anything that was protected by due process. Similarly, New York has refused to recognize this immunity as worthy of protection from retrosptetive withdrawal, ${ }^{69}$ and Illinois, in 1926, reversed its decision of two years before and initiated a line of cases, a larger group than those of any other jurisliction, which regard retroactive changes in the limiting period of compensation awards as only procedural in nature. ${ }^{70}$

So wide a divergence of authority renders extremely difficult any seneralization as to whether the immunity gained ly Clarlis employer and insurer may be classed as a property right, given the protection of the due process clause and protected against the private bill of Congress. Yet it is on the determination of these questions that the validity of that private statute, and of all private statutes in this field, is most likely to depend.

Equally difficult is an approach to the private-bill power through the realm of the separation of judicial from legislative functions, although that attempt

65. Bussey v. Bishop, 169 Ga. 251, 150 S. E. 78 (1929); Dashiell v. Holland Maide Candy Shops et al., 171 1Id. 72, 1SS Atl. 29 (1936); Holton v. Standard Sanitary MIfg. Co., 189 Atl. 194 (Md. 1937) ; Mustanen v. Diamend Coal \& Colse Co., 50 Wyo. 462, 62 Pac. (2d) 287 (1936).

66. Roles Shingle Co. v. Bergerson ot al., 142 Ore. 131, 19 P. (2d) 94 (1933); State ex rel. Roundup Coal Mining Co. v. Industrial Accident Bd., 94 Mont. 386, 23 P. (2d) 253 (1933).

67. 12 Fed. Supp. 974 (D. Penn. 1935).

68. See note 44 supra.

69. Robinson v. Robins Dry Dock \& Repair Co., 23S N. Y. 271, 144 N. E. 579 (1924); appeal disnissed, 271 U. S. 649, 46 Sup. Ct. 636 (1926); MIontgomery v. Seneen Iron \& Steel Co., 236 App. Div. 19 (3d Dep't 1932) ; Decher v. Pouvailsmith Corp., 252 X. Y. 1,168 N. E. 442 (1929).

70. Superior Coal Co. v. Industrial Comm'r, 321 III. 240, 151 N. E. $\$ 90$ (1926); Smolen v. Industrial Comm'r, 324 Ill. 32, 154 N. E. 441 (1926); Snowden \& MfeSweeney Co. v. Industrial Comm. et al., 324 Ill. 423.155 N. E. 277 (1927); Chicago Bd. of Underwriters v. Industrial Comm. ct al., 332 Ill. 611, 164 N. E. 216 (192S); Perry Coal Co. v. Industrial Comm. et al., 343 Ill. 525, 175 N. E. $\$ 01$ (1931). 
is suggested by the Wheeling decision. Compensation commissions exercise many of the attributes of courts, yet are closely controlled by Congress in respects which preclude their classification as a portion of the judiciary. ${ }^{71}$ There is very little doubt that the judgment of a court, in spite of the Whecling and Pocono cases, would be upheld against a direct attack by Congress in the shape of private legislation, provided escape by construction were not possible.72 But it does not necessarily follow that the ruling of a federal compensation commission is entitled to that protection.

The variation in treatment accorded immunities from review of compensation awards suggests, as urged before the examination of that treatment was entered upon, that the real issues involve a tacit decision as to how far the legislative body which seeks to interfere will be permitted to go before receiving judicial rebuff. The constitutionality of private acts of Congress which touch upon the administrative area is thus made to depend upon a calculation of the desirable relation between administrative tribunals, the courts and the legislature, which will probably be, nevertheless, expressed in terms of vested rights or procedural remedies. ${ }^{73}$

Since considerations like these may be expected to govern the decision of cases where Congress has exercised its private-bill power in quasi-judicial areas, constitutionality or unconstitutionality is predictable only upon a study of the hardship imposed in any particular case, modified by what the court may consider politically expedient. In cases like Paramino v. Marshall where, through compulsory insurance of the entire industry against compensation losses, the imposition of the additional award provided for by private act results actually in equality of treatment rather than discrimination, a declarntion of invalidity is hardly to be expected.

The growing complexity of administrative regulation, coupled with a tendency in the courts to limit the discretion of administrative officers wherever possible, demonstrates that it is in precisely such situations as that created by Clark's injury that the almost unexplored private-bill power of Congress can be of importance in eliminating injustices inherent in any legislation cut to a universal pattern. The adjustment of individual cases in the light of the purposes for which particular quasi-legislative tribunals were established is, potentially, a desirable reservation of Congressional power which may offset the inevitable tendency of the courts to force administrative remedies

71. The Supreme Court in Crowell v. Benson, 285 U. S. 22 (1932) refused to treat federal compensation commissions as courts for purposes of determining their own jurisdiction. The tenure and salary of deputy commissioners are entirely within the control of the United States Employees' Compensation Commission, and therefore of the executive and legislative departments. 44 STAт. 1443 (1927), 33 U. S. C. $\$ 940$ (1934). See, on this problem, Pillsbury, Administrative Tribunals (1923) 36 HARv. L. Rev. 405, 583.

72. McCullough v. Virginia, 172 U. S. 102 (1898).

73. Comment (1933) 46 HARv. L. Rev. 677, 683 urges that the considerations are always of the separation of powers, though expressed in terms of due process. 
into inflexible forms. Like all private-bill functions it is subject to political abuse and, should the volume of petitions grow markedly, may require more time than Congressional committees can profitably give.

So far as the cases reveal, it appears that the constitutionality of any particular private bill can be challenged only on the ground that it goes too far in interfering with the finality of judicial decisions. In any case this limitation may be offset, as in the Wheeling and Pocono cases, by political considerations, or as is likely in the Paramino case, by a calculation of the practical benefits and real detriments which it distributes. 